\title{
ANALISIS TINGKAT KEPUASAN MASYARAKAT DALAM PELAYANAN PUBLIK (STUDI KASUS: DI GORONTALO UTARA)
}

\author{
Zuchri Abdussamad ${ }^{1}$, Arifin Tahir ${ }^{2}$, I Kadek S. Arsana ${ }^{3 *}$ \\ ${ }^{12}$ Fakultas Ekonomi, Universitas Negeri Gorontalo, Indonesia \\ ${ }^{3}$ Fakultas Ilmu Administrasi, Sekolah Tinggi Ilmu Administrasi Bina Taruna Gorontalo, Indonesia \\ ${ }^{1}$ zuchriabdussamad@gmail.com, ${ }^{2}$ arifintahir0@gmail.com, ${ }^{3}$ satryaarsana28@gmail.com \\ *Corresponding author
}

\begin{abstract}
Abstrak: Analisis Tingkat Kepuasan Masyarakat Dalam Pelayanan Publik Studi Kasus: Di Gorontalo Utara. Pelayanan publik yang dilaksanakan oleh pemerintah daerah perlu dilakukan penilaian secara berkala. Hal ini berfungsi sebagai proses pembenahan layanan birokrasi pemerintahan. Tujuan penelitian ini adalah sebagai proses penilaian tingkat kepatuhan layanan yang diberikan oleh Organisasi Perangkat Daerah di Kabupaten Gorontalo Utara. Metode yang digunakan adalah mix metode yakni gabungan metode kualitatif dan kuantitatif. Untuk mendapat data yang valid maka terlebih dahulu dilakukan survei. Kesimpulannya hasil analisis survei pemerintah daerah Gorontalo Utara berkategori "Baik" dengan indeks sebesar 79.13. Bila dibandingkan dengan hasil indeks nilai kepatuhan pelayanan yang dipublikasikan oleh Ombudsman Republik Indonesia Tahun 2019 Kabupaten Gorontalo Utara memperoleh nilai sebesar 71.51. Berdasarkan hasil analisis tersebut menunjukkan bahwa ada peningkatan nilai indeks kepuasan pemerintah daerah Gorontalo Utara dari Tahun 2019 ke Tahun 2020 sebesar 7.62, nilai ini cukup signifikan. Artinya, Pemerintah Daerah Kabupaten Gorontalo Utara telah melakukan perbaikan-perbaikan dalam menunjang pelayanan publik pada setiap instansi di lingkungan pemerintahan.
\end{abstract}

Kata Kunci: survei kepuasan masyarakat, pelayanan public, gorontalo utara, pemerintah daerah, nilai kepatuhan

\begin{abstract}
Analysis of Public Satisfaction Level in Public Service Case Study: In North Gorontalo. Public services implemented by local governments need to be assessed periodically. This serves as a process of improving government bureaucratic services. The purpose of this research is as a process of assessing the level of compliance of services provided by the Regional Device Organization in North Gorontalo Regency. The method used is a mix of methods that are a combination of qualitative and quantitative methods. To get valid data, a survey is first conducted. In conclusion, the results of the survey analysis of the North Gorontalo regional government are categorized as "Good" with an index of 79.13. When compared with the results of the service compliance value index published by the Ombudsman of the Republic of Indonesia in 2019, North Gorontalo District obtained a value of 71.51 . Based on the results of the analysis shows that there is an increase in the satisfaction index value of the North Gorontalo regional government from 2019 to 2020 of 7.62, this value is quite significant. That is, the Regional Government of North Gorontalo Regency has made improvements in supporting public services in every agency in the government environment.
\end{abstract}

Keywords: public satisfaction survey, public service, north gorontalo, local government, compliance value.

\begin{tabular}{|c|c|c|c|}
\hline \multicolumn{4}{|c|}{ History \&License of Article Publication: } \\
\hline Received: & 04/01/2021 Revision: & 23/01/2021 Published: & $28 / 02 / 2021$ \\
\hline
\end{tabular}


Edisi Februari 2021, Volume 18 Nomor 1, ISSN 1412-1131, e-ISSN 2528-5750, Halaman 45-62

\section{PENDAHULUAN}

Provinsi Gorontalo merupakan salah satu provinsi yang dibentuk melalui pemekaran daerah di bagian utara sulawesi. Gorontalo yang dijuluki bumi serambi madinah ini terdiri atas satu kota (Kota Gorontalo) dan lima kabupaten (Gorontalo, Pohuwato, Boalemo, Bone Bolango dan Gorontalo Utara). Kabupaten Gorontalo Utara yang berbatasan langsung dengan Kabupaten Bolaang Mongondow Utara ini memiliki daerah administrasi yang cukup luas dengan beragam pulau. Merupakan daerah otonomi terbentuk tanggal 2 Januari 2007 sesuai Undang-Undang RI Nomor 11 Tahun 2007. Sejak terbentuk, Gorontalo Utara mengalami perkembangan yang cukup pesat baik pada sektor perekonomian, pendidikan, pembangunan infrastruktur, serta pemerintahan yang lebih stabil.

Hal tersebut terjadi karena adanya (Undang-Undang Nomor 23 Tahun 2014 Tentang Pemerintah Daerah, n.d.), dimana pada Bab I pasal 1 Ayat 6 menyatakan bahwa;

"Otonomi daerah adalah kekuasaan pemerintahan yang menjadi kewenangan
Presiden yang pelaksanaannya dilakukan oleh kementerian Negara dan
penyelenggara Pemerintah Daerah untuk melindungi, melayani, memberdayakan
dan menyejahterakan masyarakat"

Dari undang-undang tersebut dapat dipahami bahwa rumah tangga pemerintah daerah dilaksanakan secara otonomi oleh daerah yang bersangkutan (Hisyam, 2004), baik urusan perekonomian, pemerintahan dan kepentingan masyarakat. Tujuan dari undangundang tersebut yakni mempercepat tercapai kesejahteraan masyarakat. Selain itu juga, agar terwujud pelayanan masyarakat yang efisiensi, efektivitas, transparansi dan akuntabilitas, (Rosidah, 2006).

Berhasil atau tidak proses pelayanan yang diberikan dapat diketahui dengan cara mengukur persepsi masyarakat antara kebutuhan dan diharapkan (Kabu Khadka, 2017). Dalam proses pelayanan publik, pemerintah wajib memiliki satuan ukur yang dapat dijadikan sebuah pedoman dalam mencapai pelayanan yang berkualitas. Hal ini sejalan dengan pendapat dari (Sinaga \& Muhammad, 2020) bahwa standar layanan dapat digunakan menjadi pedoman dalam memberikan pelayanan yang berkualitas sesuai dengan komitmen dan janji dari pelaksana pelayanan. Sebagai pelaksana dalam proses pelayanan, pemerintah harus memiliki integritas dan komitmen yang mengarah untuk melindungi dan melayani masyarakat dengan baik/berkualitas (Yuningsih, 2016). Kualitas dimaksud merupakan kemampuan memberikan pelayanan yang baik, (Putra \& Arsyad, 2019). Pelayanan kualitas baik ialah suatu proses pelayanan yang tidak berbelit-belit sehingga masyarakat mendapatkan penanganan dengan cepat, memiliki alur proses yang jelas, tidak terdapat kesalahan-kesalahan serta masyarakat mendapatkan pelayanan menyenangkan 
(Wachruroji et al., 2019). Lebih lanjut dijelaskan oleh (Ramseook-Munhurrun et al., 2010) kualitas layanan merupakan penilaian keseluruhan yang mirip dengan sikap terhadap layanan dan dapat diterima oleh pelanggan dalam hal ini masyarakat.

Mengukur tingkat kepuasan masyarakat wajib dilaksanakan sebagai upaya pemenuhan asas-asas transparansi dan akuntabilitas. Sejalan dengan (Puspitasari et al., 2009) mengukur tingkat kepuasan masyarakat wajib dilaksanakan sebagai tolak ukur mengevaluasi kinerja suatu lembaga. Kepuasan layanan sangat ditentukan oleh karakteristik, kualitas pelayanan, dan disiplin pegawai (Awaludin et al., 2020). Disiplin pegawai dapat ditunjukkan melalui kualitas sumber daya manusia yang dimiliki organisasi, (Wiyono \& Lukitaningsih, 2020). Proses layanan dapat dikatakan memuaskan apabila layanan tersebut mampu mewujudkan kebutuhan serta harapan masyarakat (Tjiptono \& Chandra, 2011).

Namun, berbagai macam layanan publik yang diselenggarakan oleh pemerintahan mendapatkan feedback kurang memuaskan dari masyarakat dengan pelayanan yang disediakan. Hal ini dikarenakan prosedur pelayanan yang berbelit-belit serta kurang transparan sehingga menimbulkan krisis kepercayaan masyarakat terhadap pemerintahan (Harsono, 2005). Penelitian yang dilaksanakan oleh Silalahi (2011), dimana para pengusaha (masyarakat) menunjukkan kurang percaya terhadap pemerintah Kota Bandung, hal ini disebabkan karena rendahnya integritas, konsisten, komitmen dan loyalitas pemerintah daerah dalam memberikan pelayanan. Kemampuan pemerintah dalam menjalankan tugas dan fungsinya juga merupakan faktor penting dalam penilaian masyarakat baik buruknya kualitas pelayanan yang diterima (Dwiyanto, 2013).

Untuk melakukan perbaikan dalam proses pelayanan publik perlu diselenggarakan survei persepsi masyarakat tentang kepuasan terhadap layanan yang diberikan (Putri, 2019). Hal ini dikarenakan tipe layanan publik itu sendiri memiliki ragam jenis dengan karakteristik yang berbeda-beda, dengan demikian metode survei kepuasan masyarakat sangat cocok digunakan (Dian, 2018). Meningkatkan kualitas layanan publik sebagaimana tertuang dalam "Peraturan Menteri Pendayagunaan Aparatur Negara dan Reformasi Birokrasi (PAN \& RB) Nomor 14 tahun 2017 Tentang Survei Kepuasan Masyarakat Terhadap Penyelenggaraan Pelayanan Publik dimana Instansi pemerintah diamanatkan untuk melakukan Survei Kepuasan Masyarakat sebagai tolak ukur untuk menilai tingkat kualitas pelayanan" (PERMENPANRB, 2017). Survei ini bertujuan untuk mengetahui tingkat kinerja Organisasi Perangkat Daerah (Ningtyas \& Sari, 2019) dan perangkat 
pelayanan terkait yang diadakan survei secara periodik untuk bahan pertimbangan dalam menentukan kebijakan, (Suandi, 2019).

Berdasarkan hasil penilaian Ombudsman RI tahun 2019 tentang tingkat kepatuhan pemerintah daerah Kabupaten Gorontalo Utara secara nasional berada pada urutan ke 101 dari 215 kabupaten dengan nilai capaian 71.51. Perolehan tersebut membuat Kabupaten Gorontalo Utara berada dalam zona kuning yang artinya kepatuhan layanan publik daerah dalam kategori sedang (Ombudsman, 2019). Hal ini mengimplikasikan bahwa standar pelayanan publik Kabupaten Gorontalo Utara berdasarkan hasil tersebut perlu melakukan peningkatan sehingga pelayanan lebih optimal.

\section{METODE}

Lokasi peneliti di Kabupaten Gorontalo Utara dimana kabupaten ini berada dalam lingkup wilayah administrasi Provinsi Gorontalo. Kabupaten Gorontalo Utara dengan ibukota di Kwandang terdiri dari 11 wilayah kecamatan dengan luas wilayah administrasi adalah 1.777,022 $\mathrm{km}^{2}$ dengan ketinggian 0-2000 meter diatas permukaan laut, (Gorontalo Utara, 2020).

Metode yang digunakan dalam penelitian ini yaitu mix metode yakni gabungan metode kualitatif dan kuantitatif. Mix metode merupakan metode penelitian (kuantitatif dan kualitatif) yang dilakukan baik secara bersamaan atau secara bergantian pada kasus yang sama yang sedang diteliti secara mendalam dengan tujuan untuk mendapatkan fakta lapangan yang lebih kompehensif, (Ghasempour et al., 2014). Untuk mendapat data yang valid maka terlebih dahulu dilakukan survei (Tahir et al., 2020).

Metode kuantitatif dengan pengukuran menggunakan Skala Likert. Sehingga dalam pelaksanaan survei dikondisi pandemik Covid 19 maka mekanisme penyebaran angket dilakukan secara online melalui aplikasi Google Form. Skala Likert adalah sebuah alat ukur yang dapat dipakai dalam mengukur dari suatu sikap, pandangan seseorang atau lainnya mengenai layanan yang diperoleh (Sulistyo \& Ediwijoyo, 2020). Kemudian angket tersebut diuji kevalidannya dan reliabel angket. Hal ini bertujuan agar angket tersebut benar-benar layak dipakai dalam penelitian.

Indikator yang menjadi penilaian pada penelitian ini terdiri atas sembilan unsur berdasarkan peraturan MENPANRB yakni: 
Edisi Februari 2021, Volume 18 Nomor 1, ISSN 1412-1131, e-ISSN 2528-5750, Halaman 45-62

Tabel 1. Indikator Penelitian

\begin{tabular}{cl}
\hline No. & \multicolumn{1}{c}{ Unsur SKM } \\
\hline 1. & Persyaratan \\
2. & Sistem, Mekanisme, dan Prosedur \\
3. & Waktu Penyelesaian \\
4. & Biaya/ Tarif \\
5. & Produk Spesifikasi Jenis Pelayanan \\
6. & Kompetensi Pelaksana \\
7. & Perilaku Pelaksana \\
8. & Penanganan Pengaduan, Saran, dan Masukan \\
9. & Sarana dan Prasarana \\
10. & Penanganan Pandemic Covid 19 \\
\hline
\end{tabular}

Untuk memperoleh hasil indeks kepuasan masyarakat digunakan pendekatan nilai rata-rata tertimbang dengan rumus sebagai berikut;

$$
\text { SKM }=\frac{\text { Total dari Nilai Persepsi Per Unsur }}{\text { Total Unsur yang Terisi }} \times \text { Nilai Penimbang }
$$

Untuk mempermudah interpretasi terhadap penilaian SKM, maka hasil olahan akan dikonversikan dengan nilai dasar 25 dan nilai tertinggi 100. Sehingga mutu pelayanan dapat dikategorikan sebagai berikut;

Tabel 2. Kategori Mutu Pelayanan

\begin{tabular}{cccc}
\hline No. & Nilai Skor & Mutu & Kinerja Pelayanan \\
\hline 1. & $88,31-100,00$ & A & Sangat Baik \\
2. & $76,61-88,30$ & B & Baik \\
3. & $65,00-76,60$ & C & Cukup Baik \\
4. & $25,00-64,99$ & D & Tidak Baik \\
\hline
\end{tabular}

Survei ini ditujukan kepada seluruh Organisasi Perangkat Daerah yang ada di lingkungan pemerintahan Kabupaten Gorontalo Utara berjumlah 32 Instansi dan Badan serta 11 Kecamatan dan 15 Puskesmas di lingkungan pemerintah daerah Kabupaten Gorontalo Utara. Sehingga secara keseluruhan jumlah populasi dalam penelitian ini adalah sebanyak 48 instansi. Adanya keterbatasan waktu dan pertimbangan biaya maka sampel yang digunakan dalam penelitian ini adalah sebanyak 10 Instansi yang diklasifikasikan dalam 5 rumpun dengan tujuan kegiatan yang sama. Untuk mendapatkan data yang akurat tentang penelitian layanan publik di Kabupaten Gorontalo Utara, peneliti menyebarkan 50 (lima puluh) angket ke responden melalui google form untuk masing-masing instansi sehingga total angket yang diedarkan keseluruh instansi yang menjadi sampel penelitian yakni 500 angket. 
Edisi Februari 2021, Volume 18 Nomor 1, ISSN 1412-1131, e-ISSN 2528-5750, Halaman 45-62

Adapun rumpun organisasi perangkat daerah Kabupaten Gorontalo Utara yang menjadi sampel dalam penelitian adalah;

1. Rumpun Pemerintahan dengan sampel Dinas Kependudukan dan Catatan Sipil (Disdukcapil), Dinas Pemberdayaan Masyarakat Desa dan Kantor Kecamatan Kwandang Kabupaten Gorontalo Utara.

2. Rumpun Kesehatan yaitu sampelnya adalah Dinas Kesehatan dan Rumah Sakit Zainal Umar Sidiki.

3. Rumpun Sumber Daya Manusia, sampelnya adalah Dinas Pendidikan.

4. Rumpun Ekonomi, dengan sampel yakni Dinas Perdagangan, Koperasi \& Usaha Kecil Menengah, dan Dinas Penanaman Modal dan Perizinan Terpadu Satu Pintu.

5. Rumpun Infrastruktur, Dinas Pekerjaan Umum dan Perumahan Rakyat dan Perusahaan Daerah Air Minum.

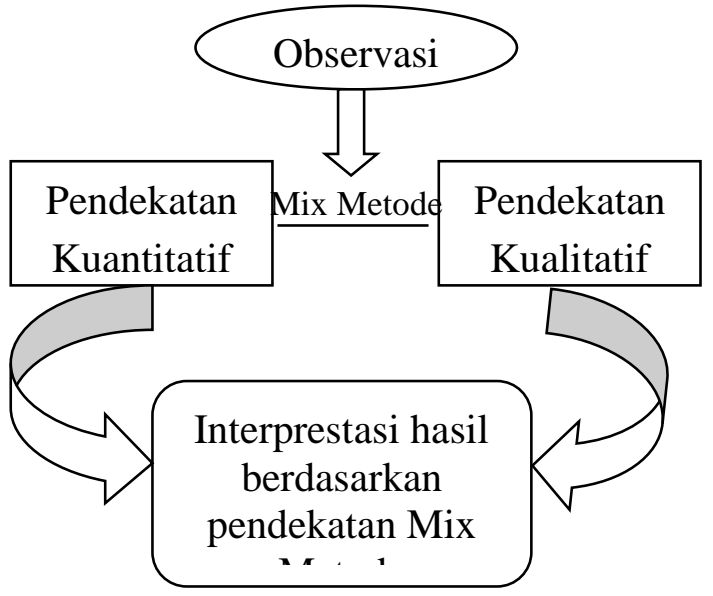

Gambar. 1 Desain Penelitian

\section{HASIL DAN PEMBAHASAN}

\section{Hasil Penelitian}

\section{Uji Angket}

Tabel 3. Uji Angket Survei Kepuasan Masyarakat Terhadap Pelayanan Publik

\begin{tabular}{cccccc}
\hline \multirow{2}{*}{ Pernyataan } & \multicolumn{3}{c}{ Validitas } & \multicolumn{2}{c}{ Reliabilitas } \\
\cline { 2 - 6 } & $\mathrm{r}_{\text {Hitung }}$ & $\mathrm{r}_{\text {Tabel }}$ & Status (V/TV) & $\begin{array}{c}\text { Cronbach } \\
\text { Alpha }\end{array}$ & Status (R/TR) \\
\hline 1 & 0.767 & 0.444 & Valid & 0.951 & Reliabel \\
2 & 0.825 & 0.444 & Valid & 0.949 & Reliabel \\
3 & 0.913 & 0.444 & Valid & 0.944 & Reliabel \\
4 & 0.825 & 0.444 & Valid & 0.949 & Reliabel \\
5 & 0.827 & 0.444 & Valid & 0.950 & Reliabel \\
6 & 0.880 & 0.444 & Valid & 0.946 & Reliabel \\
7 & 0.843 & 0.444 & Valid & 0.948 & Reliabel \\
8 & 0.792 & 0.444 & Valid & 0.950 & Reliabel \\
9 & 0.907 & 0.444 & Valid & 0.946 & Reliabel \\
10 & 0.876 & 0.444 & Valid & 0.947 & Reliabel
\end{tabular}


Edisi Februari 2021, Volume 18 Nomor 1, ISSN 1412-1131, e-ISSN 2528-5750, Halaman 45-62

Pada tabel 3 diatas dapat dilihat bahwa nilai $r_{\text {tabel }}$ diperoleh yakni 0.444 dengan $n=20$ pada taraf signifikasi $5 \%$. Sementara nilai $\mathrm{r}_{\text {hitung }}$ pada tabel 3 dapat dilihat bahwa dari sepuluh item pernyataan hasilnya semua diatas 0.444 . Sehingga dapat disimpulkan bahwa nilai $r_{\text {hitung }}$ lebih besar daripada $r_{\text {tabel. }}$ Semua angket yang digunakan dalam mengukur tingkat kepuasan masyarakat memenuhi persyaratan dan valid.

Sementara untuk uji reliabilitas angket pada tabel 3 dengan menggunakan teknik alpha croncbach, diperoleh semua pernyataan pada angket yang digunakan dalam penelitian memiliki nilai koefisien $\geq 0.6$. Kesimpulannya adalah angket yang dipakai dalam penelitian bersifat konsisten dan layak digunakan karena angket tersebut dapat dipercaya tingkat reliabilitasnya.

Tabel 4. Hasil analisis Survei Kepuasan Masyarakat Kabupaten Gorontalo Utara

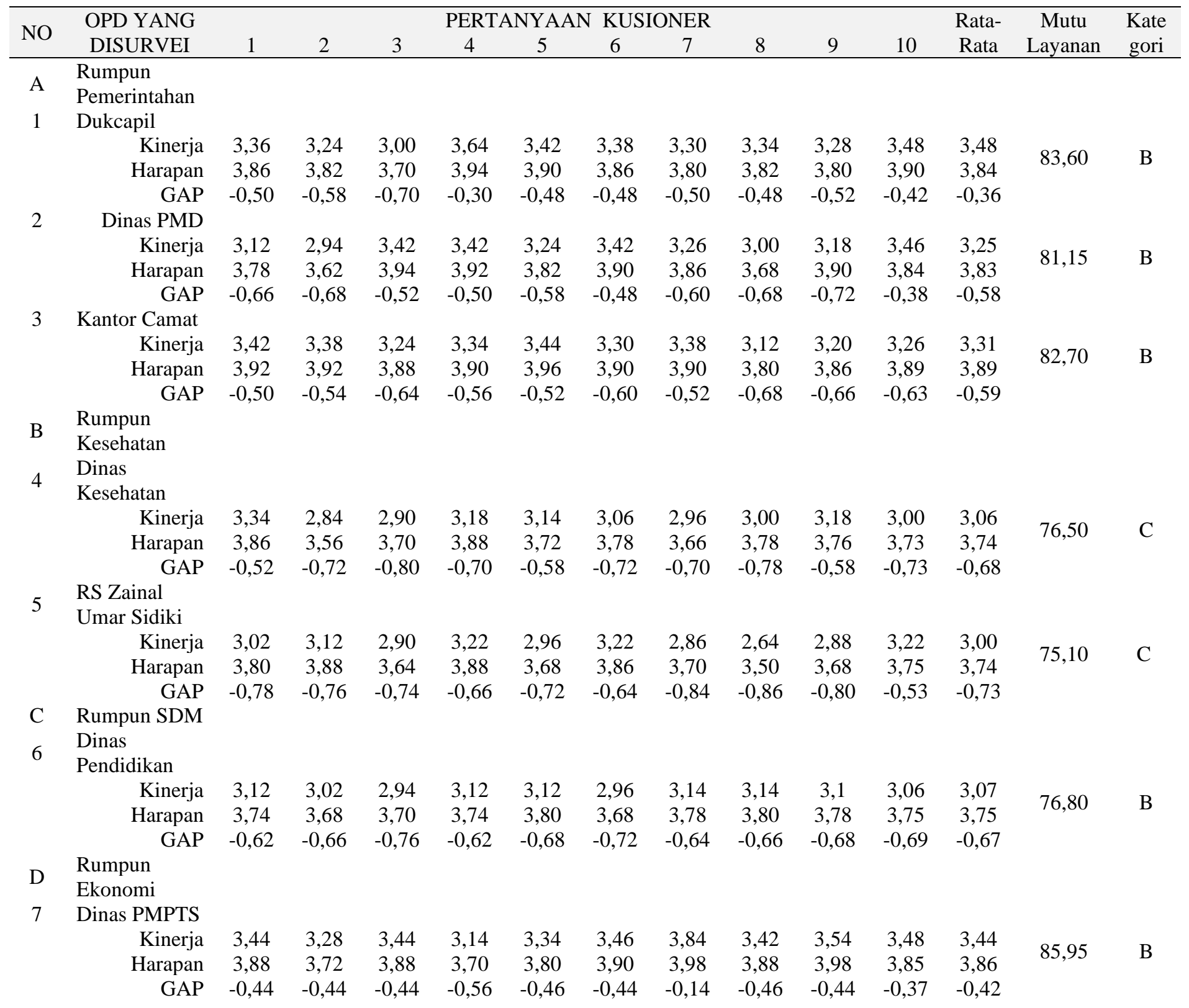




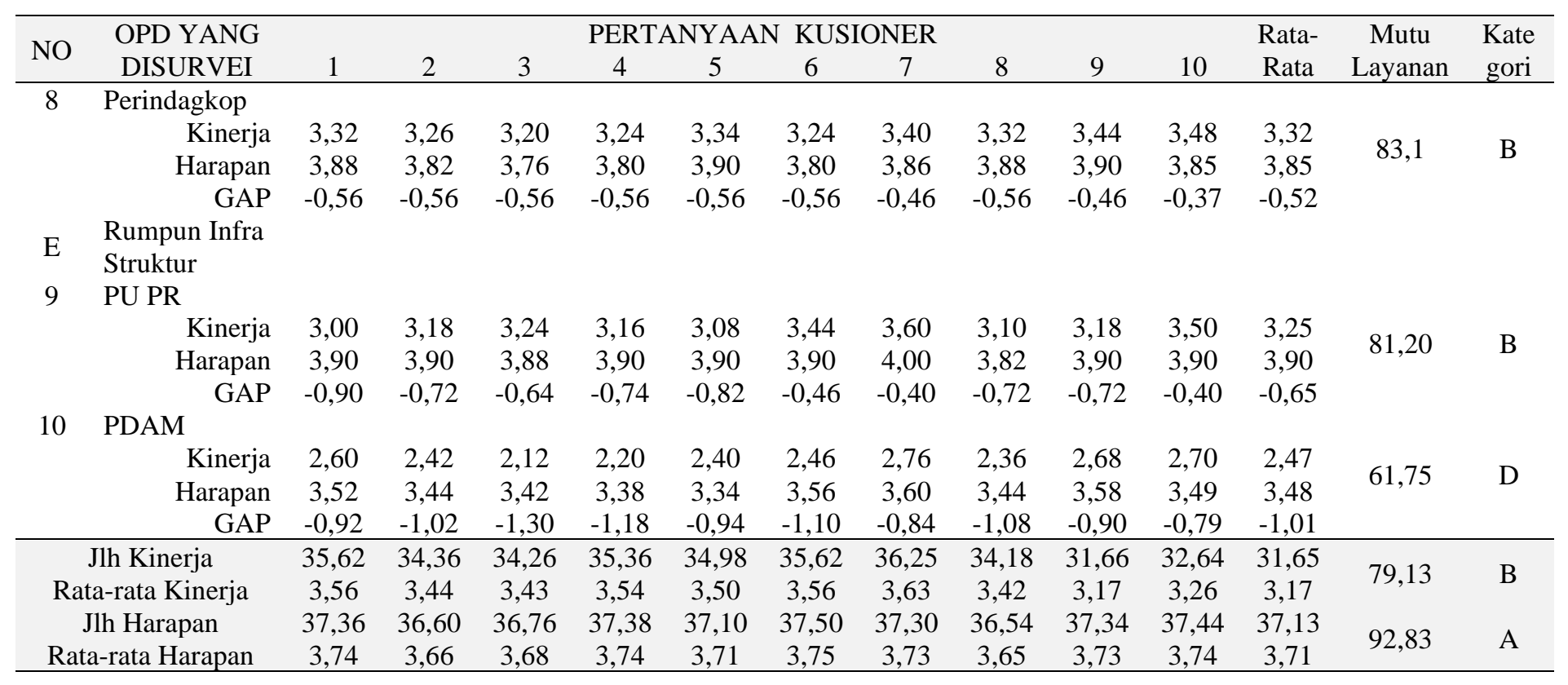

\section{Pembahasan Hasil Penelitian}

\section{a. Dinas Kependudukan dan Catatan Sipil}

Berdasarkan (Tabel 4) Menunjukkan bahwa masyarakat yang datang ke Dinas ini menilai baik terhadap pelayanan Publik yang diberikan. Dimana terdapat nilai rata-rata Kinerja Unit Layanan Dinas ini sebesar 3,34 atau rata-rata nilai interval konversi sebesar 83.80. Dalam arti kinerja unit layanan ini tergolong "baik" sedangkan nilai kesenjangan (GAP) antara kinerja dan harapan masyarakat rata-rata diperoleh sebesar -0,50.

Layanan publik yang diberikan oleh Dispenduk Capil Gorontalo Utara dengan menggunakan sepuluh unsur penilaian diperoleh bahwa terdapat tiga unsur penilaian yang kurang baik. Ketiga unsur tersebut yakni prosedur, sistem dan mekanisme; kecepatan waktu dalam memberikan layanan serta sarana dan prasarana. Berdasarkan hasil wawancara tim peneliti dilapangan layanan publik di Dispenduk Capil masih cenderung berbelit-belit, ruang tunggu atau fasilitas lainnya belum sepenuhnya optimal serta waktu yang dibutuhkan dalam pengurusan seperti KTP, kartu keluarga dan keperluan lainnya masih membutuhkan waktu yang lumayan panjang untuk dapat diterbitkan. Sehingga membuat masyarakat harus bolak balik untuk mengecek layanan yang dibutuhkan. Ketiga unsur ini perlu mendapatkan penanganan yang lebih serius. Pembenahan yang dapat dilakukan seperti konsisten dalam melakukan pelayanan, memangkas alur prosedur pelayanan yang dapat memperlambat pelayanan. Menyediakan ruang tunggu yang nyaman, terdapat fasilitas yang ber AC, ruang bermain anak-anak serta ruang menyusui. 


\section{b. Dinas Pemberdayaan Masyarakat dan Desa}

Hasil analisis kepuasan masyarakat terhadap pelayanan publik di Kabupaten Gorontalo Utara bahwa menunjukkan masyarakat yang datang ke Dinas Pemberdayaan Masyarakat dan Desa menilai "baik” terhadap pelayanan publik yang diberikan. Dimana terdapat nilai rata-rata interval sebesar 3,25 atau rata-rata nilai interval konversi sebesar 81,15 sedangkan nilai kesenjangan (GAP) antara kinerja dan harapan masyarakat rata-rata diperoleh sebesar -0,58 (Tabel 4). Adanya kesenjangan antara harapan dan kinerja pada layanan publik di dinas ini menunjukan bahwa dari unsur-unsur penilaian survei kepuasan belum sepenuhnya bekerja secara optimal sehingga perlu ada peningkatan kinerja.

Selanjutnya dalam survei ini terdapat (3) unsur layanan membutuhkan penanganan serius dari Dinas Pemberdayaan Masyarakat dan Desa yaitu Sistem, Prosedur, dan Mekanisme; Penanganan, Pengaduan, Saran, Dan Masukan dan Persyaratan pelayanan. Pembenahan yang dapat ditempuh agar dapat meningkatkan kualitas pelayanan yakni; memberikan informasi dan edukasi terkait dengan persyaratan yang dibutuhkan melalui media-media strategis seperti website, Banner, dan spanduk-spanduk yang ditempatkan pada tempat yang strategis dan mudah dibaca oleh masyarakat; memaksimalkan fungsi sarana pengaduan yang ada dan Memperbaiki prosedur pelayanan yang cepat dan tidak berbelit-belit. Sehingga prinsip pelayanan publik yang mendahulukan kepentingan umum dalam hal ini masyarakat mendapatkan kepuasan dalam menggunakan jasa, (Mulyadi, 2018).

\section{c. Kantor Camat}

Hasil analisis menunjukkan masyarakat yang datang ke Kantor Camat Kwandang menilai baik terhadap pelayanan publik yang diberikan. Dipilihnya Kantor Camat Kwandang dikarena kecamatan Kwandang merupakan ibukota dari Kabupaten Gorontalo Utara, sehingga kantor kecamatan Kwandang menjadi barometer layanan publik untuk 10 kecamatan lainnya. Dimana pada kecamatan ini terdapat nilai penilaian rata-rata sebesar 3,31 atau rata-rata nilai interval konversi sebesar 82,70 dalam arti kinerja unit layanan ini dikategorikan "baik", sedangkan nilai kesenjangan (GAP) antara kinerja dan harapan masyarakat rata-rata diperoleh sebesar -0,59 (Tabel 4).

Adapun terdapat 3 unsur layanan publik yang membutuhkan penanganan serius dari yaitu Penanganan Pengaduan, Saran dan Masukan; Sarana dan Prasarana dan Kecepatan waktu dalam memberikan pelayanan. Pada umumnya layanan yang menjadi permasalahan di organisasi perangkat daerah Gorontalo Utara terletak di kecepatan waktu serta sarana 
dan prasarana. Permasalahan sarana dan prasarana merupakan masalah yang sangat urgen yang membutuhkan penanganan segera. Lengkapnya sarana dan prasarana penunjang dalam memberikan layanan maka kecepatan waktu dalam memberikan pelayanan akan dapat lebih di efisienkan. Secara tidak langsung akan berdampak pada kualitas layanan. (Firmansyah et al., 2018) untuk meningkatkan mutu layanan perlu melakukan perbaikanperbaikan, penyediaan fasilitas penunjang layanan serta pemanfaat fasilitas penunjang secara efisien dan efektif.

\section{d. Dinas Kesehatan}

Hasil analisis survei menunjukkan bahwa masyarakat yang datang ke Dinas Kesehatan menilai "cukup baik" terhadap pelayanan publik yang diberikan. Dimana terdapat nilai rata-rata sebesar 3,06 atau rata-rata nilai interval konversi sebesar 76,50 dalam arti kinerja unit layanan ini dikategorikan "cukup baik", sedangkan nilai kesenjangan (GAP) antara kinerja dan harapan masyarakat rata-rata diperoleh sebesar -0,68 (Tabel 4). Namun, terdapat 3 unsur layanan yang membutuhkan penanganan serius dari Dinas Kesehatan Kabupaten Gorontalo Utara yaitu; Prosedur, Sistem dan Mekanisme; Waktu penyelesaian; dan Perilaku Pelaksana. Perilaku pelaksana dalam memberikan pelayanan sangat penting diperhatikan terutama terkait dengan memberikan kepuasan masyarakat dalam bidang pelayanan jasa. Komitmen serta konsisten dalam memberikan pelayanan sangat penting untuk diperhatikan. Selain itu, meningkatkan kualifikasi dan kompetensi pegawai merupakan kewajiban dari instansi. Dengan meningkatnya kualifikasi SDM yang dimiliki pasti akan berpengaruh pada mutu layanan. Sikap pelaksana merupakan faktor penting dalam pelayanan, selain diperlukan kapabilitas dalam melaksanakan pelayanan juga penting untuk diperhatikan keinginan pelaku pelaksana untuk melaksanakan pelayanan, (Tahir, 2014).

\section{e. Sakit Dr. Zainal Umar Sidiki}

Berdasarkan hasil survei Rs. Zainal Umar Sidiki menunjukkan bahwa masyarakat yang datang ke Rumah Sakit Daerah Zainal Umar Sidiki menilai "cukup baik" terhadap pelayanan publik yang diberikan. Dimana terdapat nilai rata-rata interval sebesar 3,00 atau rata-rata nilai interval konversi sebesar 75,10 sedangkan nilai kesenjangan (GAP) antara kinerja dan harapan masyarakat rata-rata diperoleh sebesar -0,73 (Tabel 4). Selanjutnya dalam survei ini terdapat 3 unsur yang membutuhkan penanganan serius dari Rumah Sakit 
Zainal Umar Sidiki, yaitu; Pengaduan, saran dan masukan; Perilaku Pelaksana; dan Sarana dan Prasarana.

Sebagian sarana dan prasarana penunjang pelayanan publik yang ada masih belum memenuhi standar pelayanan. Kelengkapan fasilitas penunjang yang dimiliki akan sangat berdampak baik terhadap kepuasan pelanggan dalam hal ini masyarakat, (Ristiani, 2017). Menurut Kotler dan Keller dalam (Setyawati et al., 2018) yang dimaksud fasilitas adalah sarana dan prasarana yang dapat menunjang kenyaman konsumen yang dengan sengaja disediakan oleh pemilik jasa.

\section{f. Dinas Pendidikan}

Berdasarkan data yang diperoleh bahwa untuk Dinas Pendidikan rata-rata masyarakat dominan datang untuk meminta layanan bantuan studi atau beasiswa dan legalisir Ijazah. Untuk pelayanan bantuan beasiswa/bantuan studi terdapat 39,50\% sedangkan untuk pelayanan legalisir ijazah sebesar $31,50 \%$ dari total 50 orang sampel sementara $30 \%$ sampel tidak mengisi/menyebutkan tipe layanan dibutuhkan.

Hasil survei di Dinas Pendidikan masyarakat menilai baik terhadap pelayanan publik yang diberikan. Dimana terdapat nilai rata-rata interval sebesar 3,07 atau rata-rata nilai interval konversi sebesar 76.80 dalam arti "baik", sedangkan nilai kesenjangan (GAP) antara kinerja dan harapan masyarakat rata-rata diperoleh sebesar -0,67 (Tabel 4). Selanjutnya dalam survei ini terdapat 3 unsur yang membutuhkan penanganan serius dari Dinas Pendidikan yaitu Waktu Penyelesaian; Kompetensi Pelaksana; dan Prosedur, Sistem dan Mekanisme. Kompetensi pelaksana berkaitan dengan kemampuan petugas dalam memberikan pelayanan. Peningkatan mutu kualitas sumber daya manusia sangat penting, sebab apabila sumber daya tidak didukung dengan kompetensi yang dimiliki implementasi pelayanan tidak akan berjalan efektif, (Mulyadi, 2018). Upaya yang dapat dilakukan dalam meningkatkan kompetensi pelaksana pelayanan adalah Memberikan pelatihan kepada tenaga petugas untuk meningkatkan kompetensi; Perlu adanya pengembangan SDM melalui peningkatan jenjang pendidikan; dan menyelenggarakan workshop/bimtek.

\section{g. Dinas Penanaman Modal dan Perizinan Terpadu Satu Pintu}

Berdasarkan hasil survei kepuasan masyarakat terhadap pelayanan publik Dinas PMPTSP Pemerintah Kabupaten Gorontalo Utara yang telah dilakukan mendapat penilaian "baik" terhadap pelayanan publik yang diberikan. Dimana terdapat nilai rata-rata interval sebesar 3,44 atau rata-rata nilai interval konversi sebesar 85.95 dalam arti 
tergolong kinerja baik, sedangkan nilai kesenjangan (GAP) antara kinerja dan harapan masyarakat rata-rata diperoleh sebesar -0,42 (Tabel 4).

Selanjutnya terdapat 3 unsur yang membutuhkan penanganan serius dari Dinas PMPTSP yaitu Standar tarif/biaya dalam pelayanan; Kemudahan prosedur pelayanan; dan Kesesuaian produk pelayanan antara yang tercantum dalam standar pelayanan dengan hasil yang diberikan. Upaya yang dapat dilakukan dalam meningkatkan kepuasan masyarakat tentang pelayanan mengenai kesesuaian atau spesifikasi produk yakni Meningkatkan sosialisasi produk dan spesifikasi layanan yang ada di masing-masing OPD melalui media cetak dan elektronik; Operator harus teliti dalam hal pengimputan data kependudukan masyarakat; Evaluasi produk dan spesifikasi layanan masing-masing OPD; dan Produk layanan dimaksimal mungkin menggunakan peralatan IT.

\section{h. Dinas Perindustrian, Perdagangan, Koperasi dan Usaha Kecil Menengah}

Hasil survei yang dilakukan di dinas ini mendapat penilaian "baik" terhadap pelayanan publik yang diberikan. Dimana terdapat nilai rata-rata interval sebesar 3,32 atau rata-rata nilai interval konversi sebesar 83.1 dalam arti tergolong kinerja baik, sedangkan nilai kesenjangan (GAP) antara kinerja dan harapan masyarakat rata-rata diperoleh sebesar -0,52 (Tabel 4). Namun dari sepuluh indikator yang menjadi penilaian pelayanan publik terdapat 3 unsur yang membutuhkan penanganan serius dari Dinas Perindagkop yaitu Waktu Penyelesaian; Biaya/Tarif; dan Kompetensi/ kemampuan petugas dalam pelayanan. Dalam pelayanan publik tarif atau biaya dapat mempengaruhi tingkat kepuasan pelanggan. (Adil et al., 2016) dimana biaya memiliki pengaruh yang nyata terhadap kepuasan pelanggan.

Kualitas pelayanan bukan hanya menjadi kebutuhan atau konsumsi dari sektor swasta, akan tetapi lembaga publik mengukur tingkat kualitas pelayanan menjadi salah satu tolok ukur tingkat keberhasilan pelayanan yang telah dilaksanakan, (Agustini, 2020). Beberapa hal yang dapat dilakukan dalam meningkatkan kualitas pelayanan mengenai biaya pelayanan yakni Memaksimalkan program, dalam mobile government; Diperlukan partisipasi dari aparat desa untuk membantu masyarakat dalam hal penjemputan dokumen kependudukan sehingga masyarakat tidak perlu lagi ke kantor; dan Transparansi pembiayaan berdasarkan regulasi yang berlaku. 


\section{i. Dinas Pekerjaan Umum dan Penataan Ruang}

Berdasarkan hasil analisis serta survei yang dilaksanakan di dinas ini bahwa masyarakat memberikan penilaian pada Dinas PU dan PR yaitu "baik" terhadap pelayanan publik yang diberikan. Dimana terdapat nilai rata-rata interval sebesar 3,25 atau rata-rata nilai interval konversi sebesar 81.20 dalam arti tergolong kinerja baik, sedangkan nilai kesenjangan (GAP) antara kinerja dan harapan masyarakat rata-rata diperoleh sebesar -0,65 (Tabel 4).

Selanjutnya dalam survei ini terdapat 3 unsur yang membutuhkan penanganan serius dari Dinas PU dan PR yaitu Persyaratan layanan; Produk spesifikasi jenis layanan; dan Penanganan pengaduan pengguna layanan. Persyaratan layanan yang diberikan di dinas PUPR masyarakat menganggap bahwa persyaratan yang ada kurang sesuai dengan jenis pelayanan yang diminta masyarakat. Hal yang perlu dilakukan dalam meningkatkan kepuasan masyarakat sebagai pengguna jasa layanan yakni Memperbaiki proses antrean masyarakat dalam mengantri untuk mendapatkan pelayanan, misalnya menyediakan nomor antrian dan tempat untuk mengantri sehingga masyarakat merasa terlayani dengan baik; dan Menindaklanjuti pengaduan, saran dan masukan dari masyarakat.

\section{j. Perusahaan Daerah Air Minum}

Hasil survei yang yang diselenggarakan tahun 2020 ini untuk mengetahui tingkat kinerja dan harapan masyarakat terhadap pelayanan publik dari PDAM Gorontalo Utara. Hasil analisis menyatakan bahwa masyarakat memberikan penilaian kepada PDAM menilai "kurang baik" terhadap pelayanan publik yang diberikan. Dimana terdapat nilai ratarata interval sebesar 2,47 atau rata-rata nilai interval konversi sebesar 61,8 sedangkan nilai kesenjangan (GAP) antara kinerja dan harapan masyarakat rata-rata diperoleh sebesar -1,00 (Tabel 4).

Selanjutnya dalam survei ini hampir semua unsur perlu memperoleh perhatian yang serius. Namun terdapat 3 unsur yang membutuhkan penanganan secepat mungkin dari PDAM, yaitu: Kewajaran tarif/ biaya dalam pelayanan; Penanganan pengaduan pengguna layanan; dan Kecepatan waktu dalam memberikan pelayanan. Penilaian yang diperoleh dari sepuluh instansi menjadi sampel penelitian, perusahaan daerah air minum menjadi instansi yang paling rendah indeks kepuasan yang diperoleh. Hal ini disebabkan karena pelayanan yang diberikan serta yang diperoleh masyarakat nilai sangat buruk oleh masyarakat. Terkadang masyarakat tidak kebagian air bersih, namun masyarakat tetap harus membayar biaya air tersebut. Selain itu, masyarakat menuturkan bahwa air yang 
diperoleh dari PDAM terkadang keruh. Pelayanan call center di PDAM juga dinilai lambat dalam menangani keluhan-keluhan masyarakat.

\section{KESIMPULAN}

Dari kesepuluh sampel OPD yang diteliti terdapat tujuh sampel organisasi perangkat daerah yang masuk dalam kategori "baik", dua OPD masuk dalam kategori "kurang baik" yakni Dinas Kesehatan dan Rumah Sakit Zainal Umar Sidiki dan satu sampel yakni perusahaan daerah "PDAM" masuk dalam kategori "tidak baik". Penilaian ini berdasarkan survei analisis kepuasan masyarakat terhadap pelayanan publik. Namun, hasil secara keseluruhan Pemerintah Daerah Kabupaten Gorontalo Utara masuk dalam kategori Baik dengan indeks kepuasan mayarakat sebesar 79.13 dalam melakukan pelayanan publik.

Implikasi penelitian ini yakni pengukuran survei kepuasan pelayanan publik yang dilaksanakan di Gorontalo Utara secara teoritis pada perbandingan pengukuran antara target dan realita kinerja pelayanan. Dengan demikian, melalui harapan atau target yang hendak dicapai pada masing-masing instansi perangkat daerah di Kabupaten Gorontalo Utara akan berusaha melakukan pembenahan pada kekurangan-kekurangan pada setiap instansi sehingga harapan atau target dapat terealisasi.

Meskipun penelitian ini sudah dilakukan secara komprehensif, namun terdapat kelemahan atau keterbatasan karena disebabkan oleh waktu dan terbatasnya biaya. Kelemahan pada penelitian ini adalah sampel penelitian yang digunakan kurang merepresentatifkan populasi yang ada.

Upaya perbaikan mengenai layanan publik di kabupaten Gorontalo utara dalam meningkatkan kualitas mutu pelayanan yakni langkah-langkah yang pertama ditempuh adalah membuat maklumat atau standar layanan yang dapat dijadikan pedoman dalam memberikan layanan dapat disebar luaskan melalui brosur, spanduk, papan pengumuman atau secara elektronik yaitu website. Yang kedua adalah membenahi sarana dan prasarana penunjang dalam memberikan pelayanan. Dengan adanya kelengkapan fasilitas maka pelayanan dapat dioptimalkan. Yang ketiga adalah melatih sumber daya manusia yang dimiliki sehingga kompetensi SDM dalam memberikan layanan lebih berkualitas. Yang terakhir adalah melakukan "Studi Tiru” ke Organisasi Perangkat Daerah dengan pelayanan publik yang memiliki nilai kepuasan masyarakat dengan kategori A, sehingga banyak yang dapat diperoleh untuk melakukan pembenahan-pembenahan untuk meningkatkan mutu kualitas pelayanan. Memperhatikan sarana dan prasarana sesuai dengan kebutuhan sehingga pelayanan dapat tercapai secara maksimal. 


\section{DAFTAR PUSTAKA}

Adil, A., Syamsun, M., \& Najib, M. (2016). Pengaruh kualitas pelayanan dan biaya terhadap kepuasan dan loyalitas pasien RSUD Kota Bogor. Jurnal Aplikasi Manajemen, 14(3), 432-441. https://doi.org/10.18202/jam23026332.14.3.04.

Agustini, S. (2020). Analisis Indeks Kepuasan Pelanggan terhadap Layanan Perencanaan, Anggaran, dan Pelaporan. EFISIENSI-KAJIAN ILMU ADMINISTRASI, 17(1), 1-14. https://doi.org/10.21831/efisiensi.v17i1.30435.

Awaludin, T., Banga, W., \& Basri, M. (2020). Pengaruh Kualitas Layanan Pegawai Terhadap Kepuasan Masyarakat (Studi Pada Pengguna Jasa Kepabeanan dan Cukai, Kantor Bea Dan Cukai Kendari). Publica: Jurnal Administrasi Pembangunan Dan Kebijakan Publik, 11(1), 72-81. https://doi.org/10.33772/publica.v11i1.12546.

Dian, A. (2018). Hasil Survey Indeks Kepuasan Masyarakat Pada Dinas Pertanahan Dan Tata Ruang Kabupaten Sleman Tahun 2017. Universitas Teknologi Yogyakarta. http://eprints.uty.ac.id/2185/1/10 ABSTRACTDIAN ALFIYANI_5140111188.pdf.

Dwiyanto, A. (2013). Mengembalikan kepercayaan publik melalui reformasi birokrasi. Gramedia Pustaka Utama.

Firmansyah, T., Supriyanto, A., \& Timan, A. (2018). Efektivitas Pemanfaatan Sarana Dan Prasarana Dalam Meningkatkan Mutu Layanan Di Sma Laboratorium. JMSP (Jurnal Manajemen Dan Supervisi Pendidikan), 2(3), 179-184. https://doi.org/10.17977/um025v2i32018p179.

Ghasempour, Z., Bakar, M. N., \& Jahanshahloo, G. R. (2014). Mix-method design in educational research: Strengths and challenges. International Journal of Pedagogical Innovations, 2(02). https://doi.org/10.12785/IJPI/020204.

Gorontalo Utara, B. (2020). Gorontalo Utara Dalam Angka 2019. Badan Pusat Statistik. https://gorontaloutarakab.bps.go.id/.

Harsono, D. (2005). Flat Organization pada Lembaga Pelayanan Publik. EFISIENSIKAJIAN ILMU ADMINISTRASI, 5(2). https://doi.org/10.21831/efisiensi.v5i2.3853.

Hisyam, D. (2004). Desentralisasi, Otonomi Daerah, dan Pembangunan. EFISIENSIKAJIAN ILMU ADMINISTRASI, 4(1). https://doi.org/10.21831/efisiensi.v4i1.3803.

Kabu Khadka, S. M. (2017). CUSTOMER SATISFACTION AND CUSTOMER LOYALTY Case Trivsel Städtjänster (Trivsel siivouspalvelut) Thesis. Marketing for Entrepreneurs and SMEs. https://doi.org/10.4337/9781781955970.00008.

Mulyadi, D. (2018). Studi Kebijakan Publik Dan Pelayanan Publik (Konsep dan Aplikasi Proses Kebijakan Publik Berbasis Analisis Bukti untuk Pelayanan Publik (Ketiga). Alfabeta.

Ningtyas, D. I. S., \& Sari, R. M. (2019). Analisis Kinerja Pelayanan Publik Puskesmas terhadap Indeks Kepuasan Masyarakat (Studi Kasus UPTD Kesehatan Kecamatan Kepanjenkidul Kota Blitar). Jurnal Penelitian Manajemen Terapan (PENATARAN), 4(2), 122-134. https://journal.stieken.ac.id/index.php/penataran/article/view/426. 
Ombudsman. (2019). Ringkasan Eksekutif Survei Kepatuhan 2019 (pp. 1-18). https://ombudsman.go.id/produk/lihat/313/LP_file_20200106_095542.pdf.

PERMENPANRB, R. (2017). Peraturan Menteri Pendayagunaan Aparatur Negara Dan Reformasi Birokrasi Republik Indonesia Nomor 14 Tahun 2017 Tentang Pedoman Penyusunan Survei Kepuasan https://jdih.menpan.go.id/data_puu/permen 14 2017.pdf.

Puspitasari, N. B., Rinawati, D. I., \& Indriartiningtias, R. (2009). Pengukuran Kepuasan Pelanggan Comlabs Institut Teknologi Bandung (ITB). J@ TI UNDIP, 4(2), 89-94. http://eprints.undip.ac.id/11103/.

Putra, F., \& Arsyad, M. (2019). Pengaruh Kualitas Sumber Daya Manusia Terhadap Kinerja Pegawai Pada Dinas Kesehatan Kabupaten Konawe Selatan. Publica: Jurnal Administrasi Pembangunan Dan Kebijakan Publik, 10(2), 11-17. https://doi.org/10.33772/publica.v10i2.10249.

Putri, B. F. (2019). Survey Kepuasan Masyarakat menjadi Sarana Peningkatan Kualitas $\begin{array}{llll}\text { Pelayanan Publik LAPAN. Buletin } & \end{array}$ https://majalah.lapan.go.id/index.php/buletin/article/view/2145.

Ramseook-Munhurrun, P., Lukea-Bhiwajee, S., \& Naidoo, P. (2010). Service Quality in the Public Service. International Journal of Management and Marketing Research.

Ristiani, I. Y. (2017). Pengaruh Sarana Prasarana dan Kualitas Pelayanan Terhadap Kepuasan Pasien (Studi Pada Pasien Rawat Jalan Unit Poliklinik IPDN Jatinegoro). Jurnal Coopetition.

Rosidah, R. (2006). Aksesibilitas Pimpinan dalam Mewujudkan Kinerja Organisasi Publik. EFISIENSI-Kajian Ilmu Administrasi, https://doi.org/10.21831/efisiensi.v6i3.3904.

Setyawati, W. A., Rifa'i, M., \& Sasmito, C. (2018). Pengaruh Kualitas Pelayanan, Fasilitas, Harga dan Citra Institusi Terhadap Kepuasan Pasien. Madani Jurnal Politik Dan Sosial Kemasyarakatan, 10(2), 50-63. http://ejurnal.unisda.ac.id/index.php/MADANI/article/view/1052.

Silalahi, U. (2011). Kepercayaan Publik kepada Pemerintah Daerah Pasca Orde Baru. JIANA (Jurnal Ilmu Administrasi Negara), 11(02). https://jiana.ejournal.unri.ac.id/index.php/JIANA/article/view/1083.

Sinaga, M. S., \& Muhammad, A. S. (2020). MELALUI SURVEI KEPUASAN MASYARAKAT: TINGKATKAN KUALITAS LAYANAN PENDIDIKAN. JIAP (Jurnal Ilmu Administrasi Publik), 8(2), 265-274. https://doi.org/10.31764/jiap.v8i2.2182.

Suandi, S. (2019). Analisis Kepuasan Masyarakat terhadap Pelayanan Publik Berdasarkan Indeks Kepuasan Masyarakat di Kantor Kecamatan Belitang Kabupaten OKU Timur. Jurnal Ilmu Administrasi Dan Studi Kebijakan (JIASK), 1(2), 13-22. https://doi.org/10.48093/jiask.v1i2.8.

Sulistyo, I. N., \& Ediwijoyo, S. P. (2020). Analisis Kepuasan Masyarakat Terhadap 
Pelayanan Publik Berdasarkan Indeks Kepuasan Masyarakat di Kantor Kecamatan Ayah Kabupaten Kebumen. Jurnal E-Bis (Ekonomi-Bisnis), 4(2), 276-286. https://doi.org/10.37339/e-bis.v4i2.386.

Tahir, A. (2014). Kebijakan Publik \& Transparansi Penyelenggaraan Pemerintah Daerah. Alfabeta.

Tahir, A., Abdussamad, Z., \& Darman, D. (2020). The Determinants of Personality Formation of Public Services in the Local Government of Pohuwato Regency, Gorontalo. BRAIN. BROAD RESEARCH IN ARTIFICIAL INTELLIGENCE AND NEUROSCIENCE. https://doi.org/10.18662/brain/11.1/21.

Tjiptono, F., \& Chandra, G. (2011). Service, Quality \& Satisfaction. In Edisi 4. https://doi.org/10.3389/fgene.2015.00293.

Undang-Undang Nomor 23 Tahun 2014 tentang Pemerintah Daerah. https://pih.kemlu.go.id/files/UU0232014.pdf.

Wachruroji, M. R., Irawani, B., \& Paselle, E. (2019). KUALITAS PELAYANAN KESEHATAN BAGI PASIEN PENGGUNA BADAN PENYELENGGARA JAMINAN SOSIAL (BPJS) DI PUSKESMAS GUNUNG SARI ILIR KECAMATAN BALIKPAPAN TENGAH. https://ejournal.ap.fisip-unmul.ac.id/site/wpcontent/uploads/2019/05/Jurnal FIX 1.2 (05-28-19-03-37-25).pdf.

Wiyono, G., \& Lukitaningsih, A. (2020). Analisis Impresi Kepemimpinan Partisipatif Dan Kompensasi Terhadap Kinerja Berbasis Kepuasan Kerja Karyawan. Efisiensi: Kajian Ilmu Administrasi, 17(2), 96-110. https://doi.org/10.21831/efisiensi.v17i2.31688.

Yuningsih, R. (2016). Kualitas Pelayanan Publik Di Kantor Perwakilan Pemerintah Daerah Kabupaten Tolitoli Di Kota Palu. Katalogis, 4(8). http://jurnal.untad.ac.id/jurnal/index.php/Katalogis/article/view/6768.

\section{UCAPAN TERIMA KASIH}

Peneliti mengucapkan banyak terima kasih atas bantuan dan kontribusi dari berbagai pihak atas terlaksananya penelitian ini, terutama kepada Badan Perencanaan Pembangunan Daerah (BAPPEDA) Pemerintah Daerah Kabupaten Gorontalo Utara.

\section{PROFIL PENULIS}

Zuchri Abdussamad, lahir di Gorontalo pada tanggal 16 Februari 1966, Memulai karir sebagai Dosen Tetap pada STKIP Negeri Gorontalo tahun 1996. Dekan FEIS Universitas Muhammadiyah Gorontalo periode tahun 2008 sd 2010 dan pada tahun 2010 sd 2011 menjadi Plt Wakil Rektor II Universitas Muhammadiyah Gorontalo. Sekertaris LPM UNG pada tahun 2011 sd 2014, pada tahun 2017 sd 2019 menjadi Ketua Program 
Edisi Februari 2021, Volume 18 Nomor 1, ISSN 1412-1131, e-ISSN 2528-5750, Halaman 45-62

Studi Doktor Administrasi Publik Pascasarjan UNG, https://scholar.google.co.id/citations?user=J5h9I84AAAAJ\&hl=id ID Sinta: 6196097

Arifin Tahir, lahir di Gorontalo pada tanggal 26 Agustus 1956, Sejak memperoleh gelar sarjana dan sampai sekarang menjadi dosen tetap Fakultas Ekonomi Universitas Negeri Gorontalo Prodi Administrasi Publik, Pada tahun 2016 dikukuhkan menjadi Guru Besar tetap bidang Administrasi Publik di Universitas Negeri Gorontalo. Disamping sebagai dosen tetap di UNG sejak tahun 2017 menjabat Direktur Pasca Sarjana di STIA Bina Taruna Gorontalo; ID Sinta: 6078446, Scopus ID: 5719119347

I Kadek Satria Arsana, lahirkan di Tohitisari, 10 Desember 1994, Sekarang penulis aktif menjadi dosen tetap di Sekolah Tinggi Ilmu Administrasi Bina Taruna Gorontalo. Selain menjadi dosen tetap penulis juga menjabat sebagai Kepala Pusat Penelitian dan Pengabdian Pada Masyarakat di STITEK Bina Taruna Gorontalo (2019 s/d sekarang). https://scholar.google.co.id/citations?user=wA6tJHMAAAAJ\&hl=id ID Sinta 6708550 